\title{
Role of Transient Receptor Potential Vanilloid 4 Channel in Skin Physiology and Pathology
}

*Ammar Boudaka, Mallak Al-Yazeedi, Intisar Al-Lawati

\section{دور قناة مُسنتَبلة فانلويد 4 ذات الجههد المؤقت في وظائف الجلد وأمراضه}

$$
\text { عمار بودقة، ملاك اليزيدية، انتصار اللواتية }
$$

ABSTRACT: Transient receptor potential vanilloid 4 (TRPV4) channel responds to temperature, as well as various mechanical and chemical stimuli. This non-selective cation channel is expressed in several organs, including the blood vessels, kidneys, oesophagus and skin. In the skin, TRPV4 channel is present in various cell types such as keratinocytes, melanocytes and sensory neurons, as well as immune and inflammatory cells, and engages in several physiological actions, from skin homeostasis to sensation. In addition, there is substantial evidence implicating dysfunctional TRPV4 channel-in the form of either deficient or excessive channel activity-in pathological cutaneous conditions such as skin barrier compromise, pruritus, pain, skin inflammation and carcinogenesis. These varied functions, combined with the fact that TRPV4 channel owns pharmacologically-accessible sites, make this channel an attractive therapeutic target for skin disorders. In this review, we summarize the different physiological and pathophysiological effects of TRPV4 in the skin.

Keywords: TRPV4; Skin; Epidermis; Keratinocytes; Pain; Pruritis; Melanoma.

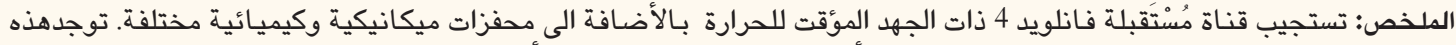

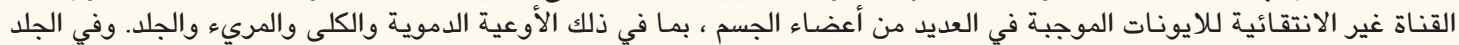

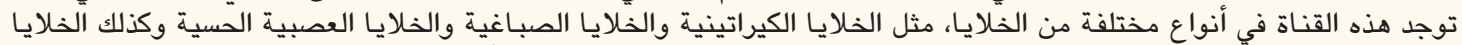

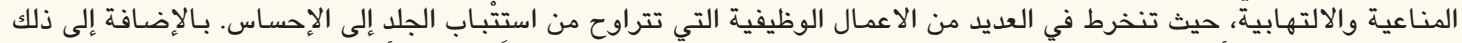

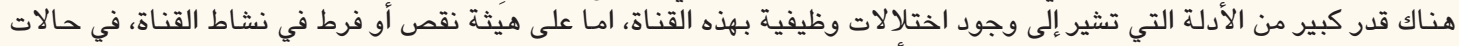

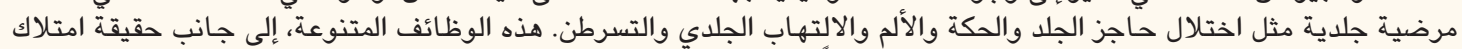

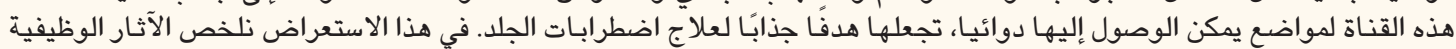

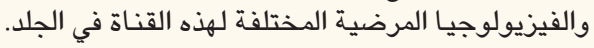

الكلمات المفتاحية؛؛ قناة مُستقَبلة فانلويد 4 ذات الجهد المؤقت؛ جلد؛ بَثَرة؛ خلايـا كيراتينية؛ ألم؛ حكة؛ ورم ميلانيني.

$\mathrm{I}$ N THE HUMAN BODY, THE SKIN IS THE LARGEST organ and is composed of three primary layers. The epidermis, the outermost superficial layer, is composed of multiple layers of keratinocytes. Basal keratinocytes divide to produce suprabasal keratinocytes that pass through several stages of differentiation and ultimately give rise to non-nucelated cells in the superficial stratum corneum. The cornified keratinocytes in conjunction with the dense intercellular structures comprise the impermeable hydrophobic skin barrier that prevents noxious substances and pathogens from getting into the human body and halts water vaporisation from the body. Melanocytes residing adjacent to the basal keratinocytes manufacture melanin and deliver it to neighboring keratinocytes. The epidermal antigen-presenting cells, known as Langerhans cells, capture exogenous and endogenous antigens and present them to the regional draining lymph nodes to provoke an immune response. The dermis, the middle layer of skin, is composed of extracellular matrix, collagen, fibroblasts, endothelial cells and mast cells. It maintains the skin through the provision of nutrients and oxygen via its extensive vascular network and is the main contributor to the physical properties of the skin as an excessive deposition of extracellular matrix, collagen and fibroblast could lead to abnormal wound healing. It also conveys the sensory nerve endings from the epidermis to the deeper layer of the skin and hosts the hair follicles. The hypodermis, the innermost layer of skin, is mainly formed of adipose tissue that functions as a heat insulator and acts as an energy storage site. ${ }^{1}$

As an integrative system, the skin maintains homeostasis, provides an immunological barrier, synthesises melanin pigments and plays a major role in sensation. Current evidence indicates that transient receptor potential (TRP) channels play a crucial role in mediating and adjusting these different functions. ${ }^{2}$ Furthermore, disturbances in the expression or function 
of these channels can result in abnormal keratinocyte differentiation, skin pigmentary and inflammatory diseases and possibly carcinogenesis.

Overall, TRP channels are non-selective cation channels that mediate the influx of calcium ions $\left(\mathrm{Ca}^{2+}\right)$, magnesium and monovalent cations into different cells. $^{2}$ A functional TRP channel is formed of a central hydrophilic channel pore surrounded by four subunits consisting of six transmembrane protein segments with $\mathrm{C}$ - and N-terminals protruding into the cytoplasm., To date, the TRP superfamily is composed of a total of 29 members divided into seven subfamilies based on amino acid arrangement, including the ankyrin, canonical, melastin, mucolipin, polycystin, no-mechanoreceptor potential and vanilloid (TRPV) subfamilies. ${ }^{2,5,6}$ These channels are found in various tissues and organs, with almost every cell expressing at least one subtype, and engage in several physiological cellular processes, including proliferation, apoptosis, cell death, mechanosensation, cell volume regulation, secretion, control of vascular permeability and blood vessel tone, as well as angiogenesis. ${ }^{7-11}$ Moreover, TRP channels can be gated by a wide range of physical and chemical stimuli such as mechanical forces, temperature and various ions and small molecules. ${ }^{12,13}$ Seemingly, TRP channels are crucial players in multiple facets of health and ailment. ${ }^{14}$

Like other tissues and organs in the body, the skin expresses many different TRP subtypes that significantly influence its proliferation, growth and integrity via different mechanisms, as well as its functioning in both healthy and diseased states. ${ }^{15,16}$ The skin has an extracellular calcium gradient, consisting of low levels near the basal keratinocytes and relatively higher concentrations around the superficial epidermal keratinocytes. Several types of TRP channels mediate calcium influx into sensory neurons, immune cells, keratinocytes and melanocytes in the skin; this potentially explains how these channels affect cellular proliferation, differentiation, cell migration, cytotoxicity and the secretion of paracrine and autocrine chemicals. ${ }^{17}$ Calcium is of particular importance to epidermal keratinocytes as it promotes their progressive differentiation while being pushed apically by actively dividing basal cells. ${ }^{18}$ Abnormal homeostasis of calcium, as in conditions such as Darier's disease or Hailey-Hailey disease, leads to poor adhesion between keratinocytes, disrupted epidermal differentiation, keratosis and other skin malfunctions. ${ }^{19,20}$

Another important function of TRP channels is their ability to cause membrane depolarisation as a result of thermal, mechanical and chemical stimuli. ${ }^{2}$ Subsequently, TRP channel-mediated depolarisation triggers action potential firing in cutaneous sensory neurons, leading to sensations of temperature, itching and pain. ${ }^{21}$ Furthermore, TRP channel stimulation can also depolarise non-excitable cells and alter other cellular processes, such as the release of adenosine triphosphate (ATP) from keratinocytes. ${ }^{22}$

The fourth member of the TRPV subfamily (TRPV4) was initially reported as an osmo- or mechanosensor that can be stimulated by moderate warmth $\left(>27^{\circ} \mathrm{C}\right)$ and ultraviolet (UV) light, as well as stimulated or inhibited by various chemical stimuli, including GSK1016790A, the synthetic phorbol ester $4 \alpha$-phorbol 12,13-didecanoate and HC-067047..23-30 Like other subtypes, TRPV4 is expressed throughout the body including the hippocampal neurons, endothelial cells, oesophageal, gastric and urinary bladder epithelia as well as skin keratinocytes, where it contributes to numerous physiological processes., ${ }^{9,26,30-33}$ Figure 1 illustrates the various functions of TRPV4 channels in different skin cells. Although several TRPV4 agonists and antagonists have been studied in animal models, none have yet been tested in human clinical trials [Table 1]. ${ }^{29,34-49}$

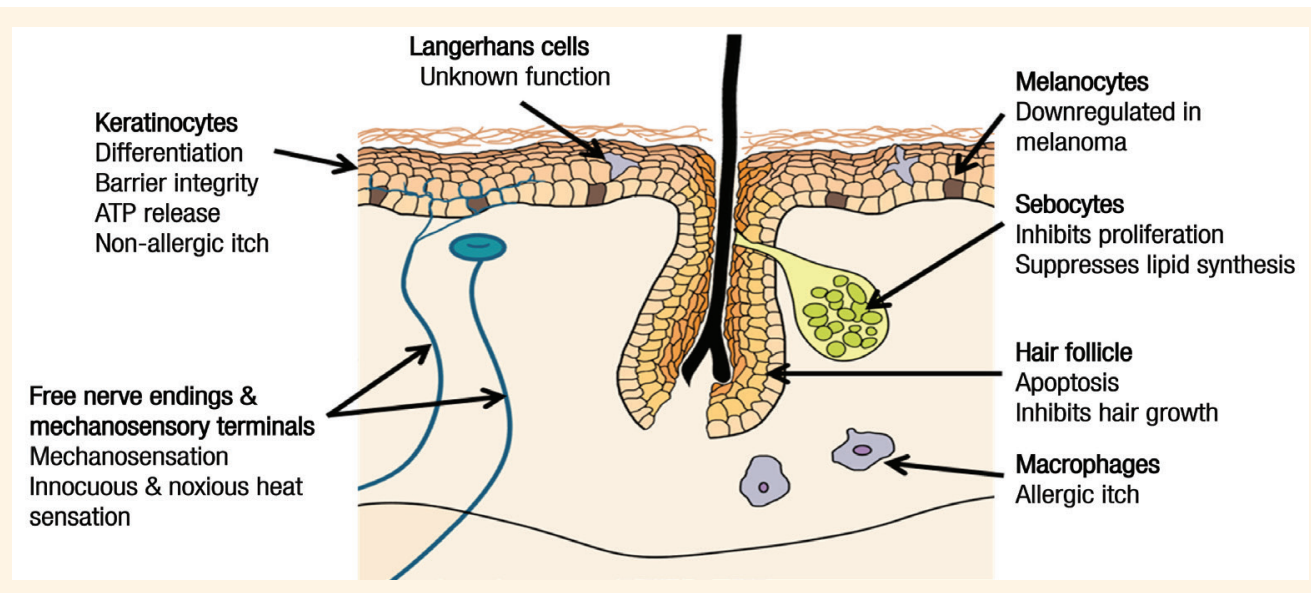

Figure 1: Diagram illustrating the functional expression of transient receptor potential vanilloid 4 channel in different skin cells. ATP $=$ adenosine triphosphate. 
This review will discuss the functional expression of TRPV4 channel in various types of cells in the skin, as well as its contribution to different cutaneous physiological and pathological processes.

\section{Epidermal Barrier Function}

In the skin, the epidermal barrier restricts extensive epidermal water loss and prevents dehydration and noxious substances and pathogens from entering the body. This barrier function is upheld by a hydrophobic

Table 1: Animal studies involving transient receptor potential vanilloid 4 channel agonists and antagonists ${ }^{29,34-49}$

\begin{tabular}{|c|c|c|}
\hline & Selectivity & $\begin{array}{l}\text { In vivo } \\
\text { (route/ } \\
\text { species) }\end{array}$ \\
\hline \multicolumn{3}{|l|}{ Agonist } \\
\hline $4 \alpha \mathrm{PDD}^{29,34}$ & Non-selective & $\begin{array}{c}\text { + (intraplantar } / \\
\text { mice })\end{array}$ \\
\hline $\mathrm{PMA}^{29}$ & Non-selective & - \\
\hline $5,6-\mathrm{EET}^{38-40}$ & Non-selective & - \\
\hline DMAPP $^{41}$ & Non-selective & $\begin{array}{c}\text { + (intraplantar } / \\
\text { mice })\end{array}$ \\
\hline $\mathrm{BAA}^{42}$ & Non-selective & - \\
\hline $\mathrm{N}$-arachidonoyl taurine $\mathrm{e}^{43}$ & Non-selective & - \\
\hline Apigenin $^{44}$ & Unknown & - \\
\hline CBDV and $\mathrm{THCV}^{29}$ & Non-selective & - \\
\hline $\mathrm{RN}-1747^{45}$ & Non-selective & - \\
\hline GSK1016790A ${ }^{29,36}$ & Non-selective & $+(\mathrm{IV}, \mathrm{SC} / \mathrm{mice})$ \\
\hline \multicolumn{3}{|l|}{ Antagonist } \\
\hline $\mathrm{Gd}^{3+46}$ & $\begin{array}{l}\text { Non-selective } \\
\text { TRPV }\end{array}$ & - \\
\hline $\mathrm{La}^{3+46}$ & $\begin{array}{l}\text { Non-selective } \\
\text { TRPV }\end{array}$ & - \\
\hline $\mathrm{RR}^{29,46,47}$ & Non-selective & - \\
\hline Capsazepine $^{48}$ & $\begin{array}{l}\text { Non-selective } \\
\text { TRPV }\end{array}$ & - \\
\hline $\mathrm{RN}-1734^{48}$ & Selective & - \\
\hline Butamben $^{48}$ & Non-selective & - \\
\hline Citral $^{48}$ & Selective & - \\
\hline GSK $205^{37,48}$ & Selective & + (topical $/$ mice $)$ \\
\hline HC-067047 $7^{35,48}$ & Selective & $+(\mathrm{SC} /$ mice $)$ \\
\hline GSK219387448,49 & Non-selective & $\begin{array}{c}+(\mathrm{IV}, \mathrm{IP} / \text { mice } \\
\quad \& \text { rats })\end{array}$ \\
\hline
\end{tabular}

$P D D=$ phorbol-12,13-didecanoate $P M A=$ phorbol 12-myristate 13-acetate; $E E T=$ epoxyeicosatrienoic acids; $D M A P P=$ dimethylallyl pyrophosphate; $B A A=$ bisandrographolide $A ; C B D V=$ cannabidivarin; $T H C V=$ tetrahydrocannabidivarin; $S C=$ subcutaneous; $I V=$ intravenous; TRPV = transient receptor potential vanilloid; Gd3+ = gadolinium; La3+ = lanthanum; $R R=$ ruthenium red; $I P=$ intraperitoneal. cornified layer formed of an uninterrupted sheet of keratin-rich cells enclosed in an extracellular unionised lipid layer. ${ }^{50,51}$ Other equally indispensable structures include the intercellular junctions underneath this cornified layer, such as the adherens junctions (AJs) and tight junctions (TJs). ${ }^{52,53}$

In mice, TRPV4 is expressed in epidermal keratinocytes and its stimulation-either by temperature or selective agonists - accelerates barrier regeneration. . $^{5,55}$ Moreover, TRPV4 is specifically colocalised with AJ components, mainly $\beta$-catenin and E-cadherin, at the plasma membrane of these keratinocytes, thus supporting its role in epidermal barrier homeostasis. ${ }^{33}$ Warm temperatures provoke TRPV4-mediated $\mathrm{Ca}^{2+}$ influx into keratinocytes, resulting in their subsequent differentiation and cell-cell contact formation. ${ }^{33}$ This promotes the development of an intact cell-cell junctiondependent barrier, including both TJs and AJs, and is disrupted in TRPV4-deficient mice. ${ }^{33}$

Thermal and chemical stimulation of TRPV4 channel also elevates intracellular calcium in human keratinocytes and contributes to the formation of intercellular junctions, thus reinforcing intercellular barrier integrity in both ex vivo and in vitro experiments, with the knockdown of this channel compromising the formation of augmented transepithelial resistance in cultures of human keratinocytes. ${ }^{56}$ Indeed, TRPV4 activation due to warm temperatures and chemical agonists reinforces the TJ-associated barrier of human keratinocytes via the upregulation of $\mathrm{TJ}$ structural proteins occludin and claudin-4, and accelerates barrier function recovery in ex vivo human skin after cornified layer removal. ${ }^{57}$ However, while there is evidence supporting the function of TRPV4 in skin barrier formation, its role in wound healing has not yet been elucidated.

\section{Sensory Functions}

There is substantial evidence supporting the involvement of TRPV4 channel in the transduction of different sensory modalities. In some cases, these functions are mediated by the neurally-expressed TRPV4 channel, while in other cases these are mediated via expression in keratinocytes and other skin-residing cells.

\section{THERMOCEPTION}

The conscious or unconscious perception of atmospheric temperature is a physiological process that is pivotal for body temperature homeostasis and the avoidance of dangerous or life-threatening thermal extremes. Cutaneously, heat is perceived by free nerve endings that connect to small diameter fibres or by epidermal keratinocytes with abundant TRPV4 expression. ${ }^{25,58}$ In 
mice, warm temperatures elicit currents in primary keratinocytes, with most heat-elicited responses seemingly mediated by TRPV $4 .{ }^{54}$

It is possible that TRPV4 participates in the $\mathrm{Ca}^{2+}$ homeostasis of keratinocytes in response to slight variations in skin temperature, which might in turn affect $\mathrm{Ca}^{2+}$-dependent processes, such as keratinocyte proliferation and differentiation or intercellular junction formation..$^{59,60}$ On the other hand, another explanation is that TRPV4 expression in keratinocytes results in the secretion of mediators such as ATP, which in turn stimulates adjacent afferent nerve fibres and, hence, the transduction of warmth. ${ }^{61-63}$ Additionally, TRPV4 is involved in sensations of innocuous warmth, although the effect in TRPV4-deficient mice was modest and condition-dependent, with the mice exhibiting preferences for slightly warmer temperatures during a thermal gradient assay. ${ }^{64}$

\section{MECHANOSENSATION}

Mechanosensation involves the transduction of mechanical stimuli into neural signals, with mechanoreceptors in the skin responsible for the sensation of touch. Both low- and high-threshold dorsal root ganglion (DRG) neurons express TRPV4 channel. ${ }^{58}$ In addition to its expression by free nerve endings, TRPV4 is also present in cutaneous mechanosensory terminals, including Merkel nerve endings, Meissner corpuscles and intraepidermal and penicillate terminals. This distribution indicates that the sensation of pressure by TRPV4 channel is transmitted through A- and C-fibres, where it plays a role in cutaneous mechanosensation..$^{58}$ Another possibility is that TRPV4 channel in keratinocytes respond to mechanical stimuli by releasing ATP, which is subsequently recognised by the neighbouring sensory fibres that mediate mechanotransduction. ${ }^{61-63}$

\section{NOCICEPTION}

Nociception refers to the detection of stimuli causing pain. Significantly elevated levels of TRPV4 expression in keratinocytes have been observed among patients with breast pain, correlating with the higher expression of nerve growth factor in these keratinocytes and, hence, sensitisation of the nociceptive nerve fibres. ${ }^{65}$ Furthermore, TRPV4 has been implicated in osmoticallyevoked pain behaviours and acute mechanical nociception, as well as mechanical hyperalgesia in inflammatory and neuropathic pain. ${ }^{66-76}$

While TRPV4 does not contribute to the normal somatosensory detection of mechanical stimuli, it plays an important role in mechanical hyperalgesia, as it interacts with $\alpha 2 \beta 1$ integrin and the Src proteintyrosine kinase to form a molecular complex that functions only in the setting of nerve injury or inflamm- ation. ${ }^{77}$ Additionally, kinins can sensitise TRPV4 to induce mechanical hyperalgesia, a mechanism thought to contribute to the maintenance of mechanical hyperalgesia and paclitaxel-induced chronic pain in mice; accordingly, these receptors may present potential targets for the treatment of chemotherapy-induced neuropathy. ${ }^{34}$

Some proalgesic factors, such as protease-activate receptor 2 agonists, also provoke mechanical hyperalgesia mediated by TRPV4 channel. ${ }^{78}$ In diabetic mice, TRPV4 blockade by the selective antagonist HC067047 prevented the development of mechanical allodynia, an effect seemingly independent of changes in the expression level of TRPV4 in the sensory neurons. ${ }^{35,79}$ Moreover, inflammation-induced thermal hyperalgesia is reportedly impaired in TRPV4-deficient mice. ${ }^{80}$

\section{Sunburn-Associated Hyperalgesia}

Additionally, TRPV4 is involved in hyperalgesia associated with sunburn. Exposure to UVB rays induced a TRPV4-mediated calcium influx into cultured mouse keratinocytes, with the subsequent release of endothelin (ET)-1, a pruriceptive/nociceptive peptide. ${ }^{81}$ Furthermore, UVB-induced inflammation, as well as thermal and mechanical hyperalgesia, are reduced in TRPV4-deficient mice or those treated with TRPV4 channel blockers. ${ }^{81}$ Following sunburn, knocking out keratinocyte-specific TRPV4 in mice curtailed the secretion of proinflammatory factor interleukin (IL)-6, consequently decreasing the numbers of recruited neutrophils and macrophages. ${ }^{81}$

Similarly, TRPV4 immunoreactivity is increased in human skin after exposure to UVB rays. ${ }^{81} \mathrm{~A}$ recent study found that $\gamma$-irradiation of keratinocytes prompted TRPV4-mediated ATP release, thereby stimulating the P2Y11 receptor and resulting in the release of IL-6 and IL- 8 via the p38 mitogen-activated protein kinase (MAPK)-nuclear factor-kB signalling pathway. ${ }^{82}$ Therefore, as both TRPV4 and ET-1 apparently play a role in acute photodermatitis in humans, TRPV4 channel may be a potential curative target for UVB- and $\gamma$ irradiation-induced dermatitides. ${ }^{82}$

\section{PRURITUS}

Chronic itching is a major clinical symptom in many skin disorders. Itch-sensitive neurons are stimulated by a wide range of exogenous itch-causing compounds (i.e. pruritogens). Additionally, keratinocytes and skinresident immune cells have the ability to release endogenous pruritogens-including ATP, ETs, prostaglandins, histamine, nitric oxide and serotonin-which can directly activate or sensitize the primary sensory neurons and cause itching, thus implying that the skin plays a role in the inception of itching sensations. . $^{83,84}$ In both humans and mice, several TRP channels are 
key mediators of itching sensations as they directly activate the peripheral pruriceptors or mediate the release of pruritogens from keratinocytes and other skin-resident cells. ${ }^{84-86}$

The involvement of TRPV4 in the sensation of itching is supported by a growing amount of data; for instance, in mice, the subcutaneous injection of GSK1016790A, a TRPV4 agonist, induced itch-related behaviours. ${ }^{36}$ Moreover, TRPV4 contributes to histamineand serotonin-induced acute itching, although its exact role is uncertain..$^{87}$ An intradermal injection of serotonin in TRPV4-deficient mice induced significantly less scratching compared to wild-type controls. ${ }^{88}$ Serotonininduced itching is also suppressed by the pharmacological inhibition of TRPV4 or 5-hydroxytryptamine (HT)-2 receptor, suggesting that 5-HT2-mediated itching is interceded by a downstream TRPV4dependent pathway. ${ }^{88}$ On the other hand, scratching behaviours evoked by histamine injection reportedly differ little between TRPV4-deficient and wild-type mice. $^{88}$

In a murine model of chronic itching, TRPV4 activation promoted downstream 5-HT signalling, with TRPV4-expressing keratinocytes and dermal macrophages involved in non-allergy- and allergy-related chronic itching, respectively. ${ }^{89}$ Moreover, scratching behaviours evoked by all histaminergic pruritogens (including histamine, ET-1 and compound 48/80) were significantly diminished in keratinocyte-specific, tamoxifen-induced TRPV4-deficient mice; moreover, the topical application of a TRPV4 blocker, GSK205, on wild-type mice also reduced scratching reactions evoked by these pruritogens. ${ }^{37}$

These findings indicate that TRPV4 channel plays a role in histaminergic itching. Histamine induces a TRPV4-dependent $\mathrm{Ca}^{2+}$ influx into the keratinocyte through the histamine $\mathrm{H} 1, \mathrm{H} 3$ or $\mathrm{H} 4$ receptors, resulting in the phosphorylation of MAPK and extracellular signal-regulated kinase (ERK), and triggering signalling of the itching sensation. ${ }^{37}$ However, it is not clear if topically-applied inhibitors of TRPV4, histamine receptors or MAPK/ERK signalling pathways also act on cutaneous sensory nerve endings in addition to skin-resident cells. Besides the phenotypic differences, whether TRPV4 expression in the skin or the DRG neurons is the main mediator of itch is still an open question; Akiyama et al. proposed that serotoninevoked scratching was mediated by TRPV4 functionally expressed in DRG neurons, whereas Chen et al. theorised that histaminergic itching was mediated by TRPV4 expressed in epidermal keratinocytes. ${ }^{37,88}$

Chloroquine (CQ) is another well-established pruritogen which can be used to induce acute histamineindependent itch model in mice. Interestingly, two studies reported different outcomes with regards to CQ-elicited itching in TRPV4-null mice; in the first, CQelicited itching was significantly elevated in TRPV4deficient mice in comparison with wild-type mice, whereas the other study found that CQ-induced scratching was not affected in TRPV4-deficient mice. ${ }^{37,88}$ Therefore, the exact role of TRPV4 in mediating acute itching warrants further research.

\section{Regulation of Hair Follicle Cycle}

A recent study reported TRPV4-positive immunoreactivity in intact human hair follicles during the anagen growth phase, with immunoreactivity detected in the cortex of the bulbar hair shaft as well as the inner and outer root sheath layers of the hair follicle epithelium..$^{90}$ Moreover, in vitro TRPV4 activation increased the number of apoptotic cells in areas with matrix keratinocytes and inhibited hair elongation, suggesting a regulatory role in hair follicle cycling. ${ }^{90}$

\section{Role in Skin Diseases}

An overview of the contribution of TRPV4 to different cutaneous diseases and its potential role in treatment is shown in Table $2 .^{33,55,57,81,91-100}$

\section{NON-MALIGNANT DISEASES}

Acne vulgaris is one of the most common skin diseases in humans and is characterised by the overproduction of sebum, unwanted sebocyte proliferation and inflammation. ${ }^{101}$ In human sebocytes, TRPV4 is functionally expressed and its activation exerts both lipostatic and antiproliferative effects. ${ }^{91}$ As such, TRPV4 could be potentially beneficial in acne treatment. Additionally, several genetic TRPV4 mutations reportedly cause Charcot-Marie-Tooth disease type 2C, a hereditary neurodegenerative disease associated with sensorimotor neuropathy. ${ }^{92-94}$

Rosacea is a chronic dermatitis that is accompanied by neurogenic inflammation. Compared with healthy skin, different types of rosacea display elevated expressions of different TRPV channels (including TRPV4), at either the molecular or protein levels, suggesting that TRPV dysregulation may be an important mechanism underlying the initiation and maintenance of this condition. ${ }^{95}$ Additionally, TRPV4 expression is elevated in both Langerhans and dermal cells in rosacea and can be stimulated under inflammatory conditions and by rosacea-related factors; accordingly, TRPV4 could be involved in the underlying inflammation in rosacea. ${ }^{95}$ A recent study revealed that TRPV4 is a key driver for 
Table 2: Potential role of transient receptor potential vanilloid 4 channel in various skin diseases ${ }^{33,55,57,81,91-100}$

\begin{tabular}{|c|c|c|}
\hline Disease & $\begin{array}{c}\text { Involvement of } \\
\text { TRPV4 }\end{array}$ & $\begin{array}{c}\text { Potential } \\
\text { therapeutic } \\
\text { benefit }\end{array}$ \\
\hline $\begin{array}{l}\text { Barrier- } \\
\text { related } \\
\text { diseases }\end{array}$ & $\begin{array}{l}\text { - Activation induces } \\
\text { barrier recovery } \\
\text { and promotes the } \\
\text { tight-junction } \\
\text { barrier between } \\
\text { keratinocytes. }{ }^{55,57,99} \\
\text { - Genetic deletion is } \\
\text { associated with leaky } \\
\text { cell-cell junctions. } \text {. }^{33,100}\end{array}$ & $\begin{array}{l}\text { - Potentially } \\
\text { beneficial } \\
\text { for treating } \\
\text { skin barrier } \\
\text { comprise } \\
\text { and inducing } \\
\text { barrier } \\
\text { recovery. }\end{array}$ \\
\hline $\begin{array}{l}\text { UV-induced } \\
\text { skin diseases }\end{array}$ & $\begin{array}{l}\text { - Involved in } \\
\text { hyperalgesia } \\
\text { associated with } \\
\text { sunburn. }^{81}\end{array}$ & $\begin{array}{l}\text { - A potential } \\
\text { curative target } \\
\text { for UVB- } \\
\text { induced and } \\
\gamma \text { irradiation- } \\
\text { induced } \\
\text { dermatitides. }\end{array}$ \\
\hline Acne vulgaris & $\begin{array}{l}\text { - Activation inhibits } \\
\text { sebocytes proliferation } \\
\text { and suppresses lipid } \\
\text { synthesis. }^{91}\end{array}$ & $\begin{array}{l}\text { - Could have } \\
\text { potentially } \\
\text { curative } \\
\text { properties. }\end{array}$ \\
\hline Rosacea & $\begin{array}{l}\text { - Mediates mast cell } \\
\text { activation. } \\
\text { - Reduces expression } \\
\text { dysregulation. }{ }^{95}\end{array}$ & $\begin{array}{l}\text { - Inhibition } \\
\text { could have } \\
\text { potentially } \\
\text { curative } \\
\text { properties. }\end{array}$ \\
\hline $\begin{array}{l}\text { Charcot Marie } \\
\text { Tooth disease } \\
\text { (type } 2 \mathrm{C} \text { ) }\end{array}$ & $\begin{array}{l}\text { - Several TRPV4 } \\
\text { mutations produce } \\
\text { neurodegenerative } \\
\text { condition including } \\
\text { dry skin and hair } \\
\text { loss. }{ }^{92-94}\end{array}$ & - \\
\hline $\begin{array}{l}\text { Malignant } \\
\text { melanoma }\end{array}$ & $\begin{array}{l}\text { - Mediates } \\
\text { cell apoptosis } \\
\text { with decreased } \\
\text { expression. }{ }^{96-98}\end{array}$ & $\begin{array}{l}\text { - Could be } \\
\text { utilised as an } \\
\text { early diagnostic } \\
\text { or prognostic } \\
\text { marker. } \\
\text { - Activation } \\
\text { could have } \\
\text { potentially } \\
\text { curative } \\
\text { properties. }\end{array}$ \\
\hline
\end{tabular}

TRPV4 = transient receptor potential vanilloid 4; $U V=$ ultraviolet .

mast cell-mediated skin inflammation in rosacea. ${ }^{102}$

\section{MALIGNANT AND PREMALIGNANT DISEASES}

Although TRPV4-related immunoreactivity and messenger ribonucleic acid transcripts are maintained at high levels in healthy or inflamed skin, they are abrogated in keratinocytic tumours. In both premalignant lesions and non-melanoma skin cancers, TRPV4 is markedly downregulated or even absent, seemingly as a result of the release of keratinocyte-derived IL-8, suggesting that the selective downregulation of TRPV4 appears to be an early diagnostic marker of skin carcinogenesis. ${ }^{96}$

Moreover, in human melanoma A375 cell lines, TRPV4 stimulation suppresses cell proliferation and induces cell apoptosis. ${ }^{97}$ A recent study revealed that TRPV4 stimulation, with calcium signalling involvement, mediates human melanoma A375 cell death by regulating the Akt pathway-driven antitumour process. ${ }^{98}$ While the involvement of TRPV4 in tumourigenesis has yet to be fully explored, these findings suggest that TRPV4 expression might serve as a prognostic or early diagnostic biomarker in human melanomas, while TRPV4 activation could even hold potentially curative properties. $^{98}$

\section{Conclusion}

Overall, TRPV4-mediated processes are not only limited to sensory functions, such as itching and pain, but also play a crucial role in keratinocyte proliferation and differentiation as well as skin barrier formation, maintenance and regeneration. Therefore, modifying TRPV4 function could improve skin barrier function, especially in conditions where there is a breach in the cornified layer-dependent barrier. Moreover, TRPV4 channel may be involved in certain diseases, thus providing possibilities for therapeutic targeting. For example, TRPV4 inhibition could help in the treatment of UVB-induced inflammation and acne vulgaris, whereas TRPV4 activation or upregulation could be of therapeutic value in the treatment of both melanoma and non-melanoma skin cancers.

\section{ACKNOWLEDGEMENT}

The authors would like to thank Ms. Malak Boudaka for her contribution to the artwork for Figure 1.

\section{References}

1. Mescher AL. Junqueira's Basic Histology: Text and atlas, 15th ed. New York, USA: McGraw Hill, 2018.

2. Nilius B, Owsianik G. The transient receptor potential family of ion channels. Genome Biol 2011; 12:218. https://doi.org/10.11 86/gb-2011-12-3-218.

3. Kassmann M, Harteneck C, Zhu Z, Nürnberg B, Tepel M, Gollasch M. Transient receptor potential vanilloid 1 (TRPV1), TRPV4, and the kidney. Acta Physiol (Oxf) 2013; 207:546-64. https://doi.org/10.1111/apha.12051.

4. Caterina MJ. Transient receptor potential ion channels as participants in thermosensation and thermoregulation. Am J Physiol Regul Integr Comp Physiol 2007; 292:R64-76. https://doi.org/10.11 52/ajpregu.00446.2006.

5. Venkatachalam K, Montell C. TRP channels. Annu Rev Biochem 2007; 76:387-417. https://doi.org/10.1146/annurev.biochem.75.1 03004.142819 .

6. Wu LJ, Sweet TB, Clapham DE. International Union of Basic and Clinical Pharmacology: LXXVI - Current progress in the mammalian TRP ion channel family. Pharmocol Rev 2010; 62:381-404. https://doi.org/10.1124/pr.110.002725.

7. Persson PB. TRPs revisited. Acta Physiol (Oxf) 2015; 214:6-7. https://doi.org/10.1111/apha.12492.

8. Yao X, Garland CJ. Recent developments in vascular endothelial cell transient receptor potential channels. Circ Res 2005; 97:853-63. https://doi.org/10.1161/01.RES.0000187473.85419.3e. 
9. Mihara H, Suzuki N, Boudaka AA, Muhammad JS, Tominaga M, Tabuchi Y, et al. Transient receptor potential vanilloid 4-dependent calcium influx and ATP release in mouse and rat gastric epithelia. World J Gastroenterol 2016; 22:5512-19. https://doi. org/10.3748/wjg.v22.i24.5512.

10. Mihara H, Boudaka A, Sugiyama T, Moriyama Y, Tominaga M. Transient receptor potential vanilloid 4 (TRPV4)-dependent calcium influx and ATP release in mouse oesophageal keratinocytes. J Physiol 2011; 589:3471-82. https://doi.org/10.1113/ jphysiol.2011.207829.

11. Mochizuki T, Sokabe T, Araki I, Fujishita K, Shibasaki K, Uchida K et al. The TRPV4 cation channel mediates stretch-evoked Ca2+ influx and ATP release in primary urothelial cell cultures. J Biol Chem 2009; 284:21257-64. https://doi.org/10.1074/jbc.M1 09.020206 .

12. Caterina MJ, Julius D. The vanilloid receptor: A molecular gateway to the pain pathway. Annu Rev Neurosci 2001; 24:487-517. https://doi.org/10.1146/annurev.neuro.24.1.487.

13. Flockerzi V. An introduction on TRP channels. Handb Exp Pharmacol 2007; 179:1-19. https://doi.org/10.1007/978-3-540-34891-7_1.

14. Nilius B, Owsianik G, Voets T, Peters JA. Transient receptor potential cation channels in disease. Physiol Rev 2007; 87:165-217. https://doi.org/10.1152/physrev.00021.2006.

15. Lumpkin EA, Caterina MJ. Mechanisms of sensory transduction in the skin. Nature 2007; 445:858-65. https://doi.org/10.1038/ nature05662.

16. Caterina MJ. TRP channel cannabinoid receptors in skin sensation, homeostasis, and inflammation. ACS Chem Neurosci 2014; 5:1107-16. https://doi.org/10.1021/cn5000919.

17. Tóth BI, Oláh A, Szöllősi AG, Bíró T. TRP channels in the skin. Br J Pharmacol 2014; 171:2568-81. https://doi.org/10.1111/ bph.12569.

18. Yuspa SH, Henninngs H, Tucker RW, Jaken S, Kilkenny AE, Roop DR. Signal transduction for proliferation and differentiation in keratinocytes. Ann N Y Acad Sci 1988; 548:191-96. https://doi.org/10.1111/j.1749-6632.1988.tb18806.x.

19. Sakuntabhai A, Dhitavat J, Burge S, Hovnanian A. Mosaicism for ATP2A2 mutations causes segmental Darier's disease. J Invest Dermatol 2000; 115:1144-7. https://doi.org/10.1046/j.15 23-1747.2000.00182.x.

20. Hu Z, Bonifas JM, Beech J, Bench G, Shigihara T, Ogawa H, et al. Mutations in ATP2C1, encoding a calcium pump, cause Hailey-Hailey disease. Nat Genet 2000; 24:61-5. https://doi. org $/ 10.1038 / 71701$

21. Basbaum AI, Bautista DM, Scherrer G, Julius D. Cellular and molecular mechanisms of pain. Cell 2009; 139:267-84. https://doi.org/10.1016/j.cell.2009.09.028.

22. Zhao P, Barr TP, Hou Q, Dib-Hajj SD, Black JA, Albrecht PJ, et al. Voltage-gated sodium channel expression in rat and human epidermal keratinocytes: Evidence for a role in pain. Pain 2008; 139:90-105. https://doi.org/10.1016/j.pain.2008.03.016.

23. Liedtke W, Choe Y, Martí-Renom MA, Bell AM, Denis CS, Sali A, et al. Vanilloid receptor-related osmotically activated channel (VR-OAC), a candidate vertebrate osmoreceptor. Cell 2000; 103:525-35. https://doi.org/10.1016/S0092-8674(00)00143-4.

24. Strotmann R, Harteneck C, Nunnenmacher K, Schultz G, Plant TD. OTRPC4, a nonselective cation channel that confers sensitivity to extracellular osmolarity. Nat Cell Biol 2000; 2:695-702. https://doi.org/10.1038/35036318.

25. Güler AD, Lee H, Iida T, Shimizu I, Tominaga M, Caterina M. Heat-evoked activation of the ion channel, TRPV4. J Neurosci 2002; 22:6408-14. https://doi.org/10.1523/JNEUROSCI.22-1506408.2002 .

26. Watanabe H, Vriens J, Suh SH, Benham CD, Droogmans G, Nilius B. Heat-evoked activation of TRPV4 channels in a HEK293 cell expression system and in native mouse aorta endothelial cells. J Biol Chem 2002; 277:47044-51. https://doi. org/10.1074/jbc.M208277200.
27. White JP, Cibelli M, Urban L, Nilius B, McGeown JG, Nagy I. TRPV4: Molecular conductor of a diverse orchestra. Physiol Rev 2016; 96:911-73. https://doi.org/10.1152/physrev.00016.2015.

28. Willette RN, Bao W, Nerurkar S, Yue TL, Doe CP, Stankus G, et al. Systemic activation of the transient receptor potential vanilloid subtype 4 channel causes endothelial failure and circulatory collapse: Part 2. J Pharmacol Exp Ther 2008; 326:443-52. https://doi.org/10.1124/jpet.107.134551.

29. Watanabe H, Davis JB, Smart D, Jerman JC, Smith GD, Hayes P, et al. Activation of TRPV4 channels (hVRL-2/mTRP12) by phorbol derivatives. J Biol Chem 2002; 277:13569-77. https://doi.org/10.1074/jbc.M200062200.

30. Everaerts W, Zhen X, Ghosh D, Vriens J, Gevaert T, Gilbert JP, et al. Inhibition of the cation channel TRPV4 improves bladder function in mice and rats with cyclophosphamideinduced cystitis. Proc Natl Acad Sci U S A 2010; 107:19084-9. https://doi.org/10.1073/pnas.1005333107.

31. Shibasaki K, Suzuki M, Mizuno A, Tominaga M. Effects of body temperature on neural activity in the hippocampus: Regulation of resting membrane potentials by transient receptor potential vanilloid 4. J Neurosci 2007; 27:1566-75. https://doi.org/10.1523/JNEUROSCI.4284-06.2007.

32. Boudaka A, Al-Suleimani M, Al-Lawati I, Baomar H, Al-Siyabi S, Zadjali F. Downregulation of endothelial transient receptor potential vanilloid type 4 channel underlines impaired endothelial nitric oxide-mediated relaxation in the mesenteric arteries of hypertensive rats. Physiol Res 2019; 8408:219-31. https://doi.org/10.33549/physiolres.933952.

33. Sokabe T, Fukumi-Tominaga T, YonemuraS, MizunoA, Tominaga M. The TRPV4 channel contributes to intercellular junction formation in keratinocytes. J Biol Chem 2010; 285:18749-58. https:// doi.org/10.1074/jbc.M110.103606

34. Costa R, Bicca MA, Manjavachi MN, Segat GC, Dias FC, Fernandes ES, et al. Kinin receptors sensitize TRPV4 channel and induce mechanical hyperalgesia: Relevance to paclitaxelinduced peripheral neuropathy in mice. Mol Neurobiol 2018; 55:2150-61. https://doi.org/10.1007/s12035-017-0475-9.

35. Dias FC, Alves VS, Matias DO, Figueiredo CP, Miranda ALP, Passos GF, et al. The selective TRPV4 channel antagonist HC067047 attenuates mechanical allodynia in diabetic mice. Eur J Pharmacol 2019; 856:172408. https://doi.org/10.1016/j.ejph ar.2019.172408.

36. Kittaka H, Yamanoi Y, Tominaga M. Transient receptor potential vanilloid 4 (TRPV4) channel as a target of crotamiton and its bimodal effects. Pflugers Arch 2017; 469:1313-23. https://doi.org/10.1007/s00424-017-1998-7.

37. Chen Y, Fang Q, Wang Z, Zhang JY, MacLeod AS, Hall RP, et al. Transient receptor potential vanilloid 4 ion channel functions as a pruriceptor in epidermal keratinocytes to evoke histaminergic itch. J Biol Chem 2016; 291:10252-62. https://doi.org/10.1074/jbc.M116.716464.

38. Vriens J, Owsianik G, Fisslthaler B, Suzuki M, Janssens A, Voets T, et al. Modulation of the Ca2 permeable cation channel TRPV4 by cytochrome P450 epoxygenases in vascular endothelium. Circ Res 2005; 97:908-15. https://doi.org/10.1161/01.RES.000 0187474.47805.30.

39. Vriens J, Owsianik G, Janssens A, Voets T, Nilius B. Determinants of 4 alpha-phorbol sensitivity in transmembrane domains 3 and 4 of the cation channel TRPV4. J Biol Chem 2007; 282:12796-803. https://doi.org/10.1074/jbc.M610485200.

40. Watanabe H, Vriens J, Prenen J, Droogmans G, Voets T, Nillus B. Anandamide and arachidonic acid use epoxyeicosatrienoic acids to activate TRPV4 channels. Nature 2003; 424:434-8. https://doi.org/10.1038/nature01807.

41. Bang S, Yoo S, Yang TJ, Cho H, Hwang SW. Nociceptive and pro-inflammatory effects of dimethylallyl pyrophosphate via TRPV4 activation. Br J Pharmacol 2012; 166:1433-43. https://doi.org/10.1111/j.1476-5381.2012.01884.x. 
42. Smith PL, Maloney KN, Pothen RG, Clardy J, Clapham DE. Bisandrographolide from Andrographis paniculata activates TRPV4 channels. J Biol Chem 2006; 281:29897-904. https://doi.org/10.1074/jbc.M605394200.

43. Saghatelian A, McKinney MK, Bandell M, Patapoutian A, Cravatt BF. A FAAH-regulated class of $\mathrm{N}$-acyl taurines that activates TRP ion channels. Biochemistry 2006; 45:9007-15. https://doi.org/10.1021/bi0608008.

44. Ma X, He D, Ru X, Chen Y, Cai Y, Bruce IC, et al. Apigenin, a plant-derived flavone, activates transient receptor potential vanilloid 4 cation channel. Br J Pharmacol 2012; 166:349-58. https://doi.org/10.1111/j.1476-5381.2011.01767.x.

45. Klausen TK, Pagani A, Minassi A, Ech-Chahad A, Prenen J, Owsianik G, et al. Modulation of the transient receptor potential vanilloid channel TRPV4 by 4alpha-phorbol esters: A structure-activity study. J Med Chem 2009; 52:2933-9. https://doi.org/10.1021/jm9001007.

46. Nilius B, Vriens J, Prenen J, Droogmans G, Voets T. TRPV4 calcium entry channel: A paradigm for gating diversity. Am J Physiol Cell Physiol 2004; 286:C195-205. https://doi.org/10.1152/ajpcell.00 365.2003.

47. Lee JH, Park C, Kim SJ, Kim HJ, Oh GS, Shen A, et al. Different uptake of gentamicin through TRPV1 and TRPV4 channels determines cochlear hair cell vulnerability. Exp Mol Med 2013; 45:e12. https://doi.org/10.1038/emm.2013.25.

48. Vincent F, Acevedo A, Nguyen MT, Dourado M, DeFalco J, Gustafson A, et al. Identification and characterization of novel TRPV4 modulators. Biochem Biophys Res Commun 2009; 389:490-4. https://doi.org/10.1016/j.bbrc.2009.09.007.

49. Gradilone SA, Masyuk TV, Huang BQ, Banales JM, Lehmann GL, Radtke BN, et al. Activation of TRPV4 reduces the hyperproliferative phenotype of cystic cholangiocytes from an animal model of ARPKD. Gastroenterology 2010; 139:304-14.e2. https://doi.org/10.1053/j.gastro.2010.04.010

50. Kalinin AE, Kajava AV, Steinert PM. Epithelial barrier function: Assembly and structural features of the cornified cell envelope. Bioessays 2002; 24:789-800. https://doi.org/10.1002/bies.10144.

51. Proksch E, Brandner JM, Jensen JM. The skin: An indispensable barrier. Exp Dermatol 2008; 17:1063-72. https://doi.org/10.11 11/j.1600-0625.2008.00786.x.

52. Tsukita S, Furuse M. Claudin-based barrier in simple and stratified cellular sheets. Curr Opin Cell Biol 2002; 14:531-6. https://doi.org/10.1016/S0955-0674(02)00362-9.

53. Niessen CM. Tight junctions/adherens junctions: Basic structure and function. J Invest Dermatol 2007; 127:2525-32. https://doi.org/10.1038/sj.jid.5700865.

54. Chung MK, Lee H, Mizuno A, Suzuki M, Caterina MJ. TRPV3 and TRPV4 mediate warmth-evoked currents in primary mouse keratinocytes. J Biol Chem 2004; 279:21569-75. https://doi.org/10.1074/jbc.M401872200.

55. Denda M, Sokabe T, Fukumi-Tominaga T, Tominaga M. Effects of skin surface temperature on epidermal permeability barrier homeostasis. J Invest Dermatol 2007; 127:654-9. https://doi. org/10.1038/sj.jid.5700590.

56. Kida N, Sokabe T, Kashio M, Haruna K, Mizuno Y, Suga Y, et al. Importance of transient receptor potential vanilloid 4 (TRPV4) in epidermal barrier function in human skin keratinocytes. Pflugers Arch 2012; 463:715-25. https://doi.org/10.1007/s004 24-012-1081-3.

57. Akazawa Y, Yuki T, Yoshida H, Sugiyama Y, Inoue S. Activation of TRPV4 strengthens the tight-junction barrier in human epidermal keratinocytes. Skin Pharmacol Physiol 2013; 26:15-21. https://doi.org/10.1159/000343173.
58. Suzuki M, Watanabe Y, Oyama Y, Mizuno A, Kusano E, Hirao A, et al. Localization of mechanosensitive channel TRPV4 in mouse skin. Neurosci Lett 2003; 353:189-92. https://doi.org/10.1016/j. neulet.2003.09.041.

59. Hennings H, Michael D, Cheng C, Steinert P, Holbrook K, Yuspa SH. Calcium regulation of growth and differentiation of mouse epidermal cells in culture. Cell 1980; 19:245-54. https://doi.org/10.1016/0092-8674(80)90406-7.

60. Watt FM, Mattey DL, Garrod DR. Calcium-induced reorganization of desmosomal components in cultured human keratinocytes. J Cell Biol 1984; 99:2211-15. https://doi.org/10.1083/ jcb.99.6.2211.

61. Peier AM, Reeve AJ, Andersson DA, Moqrich A, Earley TJ, Hergarden AC, et al. A heat-sensitive TRP channel expressed in keratinocytes. Science 2002; 296:2046-9. https://doi.org/10.1 126/science.1073140.

62. Chung MK, Lee H, Caterina MJ. Warm temperatures activate TRPV4 in mouse 308 keratinocytes. J Biol Chem 2003; 278:32037-46. https://doi.org/10.1074/jbc.M303251200.

63. Souslova V, Cesare P, Ding Y, Akopian AN, Stanfa L, Suzuki R, et al. Warm-coding deficits and aberrant inflammatory pain in mice lacking P2X3 receptors. Nature 2000; 407:1015-17. https://doi.org/10.1038/35039526.

64. Lee H, Iida T, Mizuno A, Suzuki M, Caterina MJ. Altered thermal selection behavior in mice lacking transient receptor potential vanilloid 4. J Neurosci 2005; 25:1304-10. https://doi. org/10.1523/JNEUROSCI.4745.04.2005.

65. Gopinath P, Wan E, Holdcroft A, Facer P, Davis JB, Smith GD, et al. Increased capsaicin receptor TRPV1 in skin nerve fibres and related vanilloid receptors TRPV3 and TRPV4 in keratinocytes in human breast pain. BMC Womens Health 2005; 5:2. https://doi.org/10.1186/1472-6874-5-2.

66. Alessandri-Haber N, Joseph E, Dina OA, Liedtke W, Levine JD. TRPV4 mediates pain-related behavior induced by mild hypertonic stimuli in the presence of inflammatory mediator. Pain 2005; 118:70-9. https://doi.org/10.1016/j.pain.2005.07.016.

67. Alessandri-Haber N, Yeh JJ, Boyd AE, Parada CA, Chen X, Reichling DB, et al. Hypotonicity induces TRPV4-mediated nociception in rat. Neuron 2003; 39:497-511. https://doi.org/10.1 016/S0896-6273(03)00462-8

68. Liedtke W, Friedman JM. Abnormal osmotic regulation in TRPV4-/- mice. Proc Natl Acad Sci U S A 2003; 100:13698-703. https://doi.org/10.1073/pnas.1735416100.

69. Suzuki M, Mizuno A, Kodaira K, Imai M. Impaired pressure sensation in mice lacking TRPV4. J Biol Chem 2003; 278:22664-8. https://doi.org/10.1074/jbc.M302561200.

70. Segond von Banchet G, Boettger MK, König C, Iwakura Y, Bräuer R, Schaible HG. Neuronal IL-17 receptor upregulates TRPV4 but not TRPV1 receptors in DRG neurons and mediates mechanical but not thermal hyperalgesia. Mol Cell Neurosci 2013; 52:152-60. https://doi.org/10.1016/j.mcn.2012.11.006.

71. Sierra H, Cordova M, Chen CJ, Rajadhyaksha M. Confocal imaging-guided laser ablation of basal cell carcinomas: An ex vivo study. J Invest Dermatol 2015; 135:612-15. https://doi.org/10.1 038/jid.2014.371.

72. Chen Y, Williams SH, McNulty AL, Hong JH, Lee SH, Rothfusz NE, et al. Temporomandibular joint pain: A critical role for TRPV4 in the trigeminal ganglion. Pain 2013; 154:1295-304. https://doi.org/10.1016/j.pain.2013.04.004.

73. Alessandri-Haber N, Dina OA, Joseph EK, Reichling D, Levine JD. A transient receptor potential vanilloid 4-dependent mechanism of hyperalgesia is engaged by concerted action of inflammatory mediators. J Neurosci 2006; 26:3864-74. https://doi.org/10.1 523/JNEUROSCI.5385-05.2006. 
74. Alessandri-Haber N, Dina OA, Yeh JJ, Parada CA, Reichling DB, Levine JD. Transient receptor potential vanilloid 4 is essential in chemotherapy-induced neuropathic pain in the rat. J Neurosci 2004; 24:4444-52. https://doi.org/10.1523/JNEUROSCI.024 2-04.2004.

75. Chen Y, Yang C, Wang ZJ. Proteinase-activated receptor 2 sensitizes transient receptor potential vanilloid 1, transient receptor potential vanilloid 4 , and transient receptor potential ankyrin 1 in paclitaxel-induced neuropathic pain. Neuroscience 2011; 193:440-51. https://doi.org/10.1016/j.neuroscien ce.2011.06.085

76. Ding XL, Wang YH, Ning LP, Zhang Y, Ge HY, Jiang H, et al. Involvement of TRPV4-NO-cGMP-PKG pathways in the development of thermal hyperalgesia following chronic compression of the dorsal root ganglion in rats. Behav Brain Res 2010; 208:194-201. https://doi.org/10.1016/j.bbr.2009.11.034.

77. Alessandri-Haber N, Dina OA, Joseph EK, Reichling DB, Levine JD. Interaction of transient receptor potential vanilloid 4, integrin, and Src tyrosine kinase in mechanical hyperalgesia. J Neurosci 2008; 28:1046-57. https://doi.org/10.1523/JNEURO SCI.4497-07.2008

78. Grant AD, Cottrell GS, Amadesi S, Trevisani M, Nicoletti P, Materazzi S, et al. Protease-activated receptor 2 sensitizes the transient receptor potential vanilloid 4 ion channel to cause mechanical hyperalgesia in mice. J Physiol 2007; 578:715-33. https://doi.org/10.1113/jphysiol.2006.121111.

79. Facer P, Casula MA, Smith GD, Benham CD, Chessell IP, Bountra C, et al. Differential expression of the capsaicin receptor TRPV1 and related novel receptors TRPV3, TRPV4 and TRPM8 in normal human tissues and changes in traumatic and diabetic neuropathy. BMC Neurol 2007; 7:11. https://doi. org/10.1186/1471-2377-7-11

80. Todaka H, Taniguchi J, Satoh JI, Mizuno A, Suzuki M. Warm temperature-sensitive transient receptor potential vanilloid 4 (TRPV4) plays an essential role in thermal hyperalgesia. J Biol Chem 2004; 279:35133-8. https://doi.org/10.1074/jbc.M4 06260200

81. Moore C, Cevikbas F, Pasolli HA, Chen Y, Kong W, Kempkes C, et al. UVB radiation generates sunburn pain and affects skin by activating epidermal TRPV4 ion channels and triggering endothelin-1 signaling. Proc Natl Acad Sci U S A 2013; 110:E3225-34. https://doi.org/10.1073/pnas.1312933110.

82. Ohsaki A, Tanuma SI, Tsukimoto M. TRPV4 channel-regulated ATP release contributes to $\gamma$-irradiation-induced production of IL-6 and IL-8 in epidermal keratinocytes. Biol Pharm Bull 2018; 41:1620-6. https://doi.org/10.1248/bpb.b18-00361.

83. Bautista DM, Wilson SR, Hoon MA. Why we scratch an itch: The molecules, cells and circuits of itch. Nat Neurosci 2014; 17:175-82. https://doi.org/10.1038/nn.3619.

84. Xie Z, Hu H. TRP channels as drug targets to relieve itch. Pharmaceuticals 2018; 11:E100. https://doi.org/10.3390/ph110 40100

85. Akiyama T, Carstens E. Neural processing of itch. Neuroscience 2013; 250:697-714. https://doi.org/10.1016/j.neurosci ence.2013.07.035.

86. Luo J, Feng J, Liu S, Walters ET, Hu H. Molecular and cellular mechanisms that initiate pain and itch. Cell Mol Life Sci 2015; 72:3201-23. https://doi.org/10.1007/s00018-015-1904-4.

87. Caterina MJ, Pang Z. TRP channels in skin biology and pathophysiology. Pharmaceuticals (Basel) 2016; 9:E77. https://doi.org/10.3390/ph9040077.

88. Akiyama T, Ivanov M, Nagamine M, Davoodi A, Carstens MI, Ikoma A, et al. Involvement of TRPV4 in serotonin-evoked scratching. J Invest Dermatol 2016; 136:154-60. https://doi.org/10.10 38/JID.2015.388.
89. Luo J, Feng J, Yu G, Yang P, Mack MR, Du J, et al. Transient receptor potential vanilloid 4-expressing macrophages and keratinocytes contribute differentially to allergic and nonallergic chronic itch. J Allergy Clin Immunol 2018; 141:608-19.e7. https://doi.org/10.1016/j.jaci.2017.05.051.

90. Szabó IL, Herczeg-Lisztes E, Szegedi A, Nemes B, Paus R, Bíró T, et al. TRPV4 is expressed in human hair follicles and inhibits hair growth in vitro. J Invest Dermatol 2019; 139:1385-8. https://doi.org/10.1016/j.jid.2018.11.020

91. Oláh A, Tóth BI, Borbíró I, Sugawara K, Szöllõsi AG, Czifra G, et al. Cannabidiol exerts sebostatic and antiinflammatory effects on human sebocytes. J Clin Invest 2014; 124:3713-24. https://doi.org/10.1172/JCI64628.

92. Auer-Grumbach M, Olschewski A, Papić L, Kremer H, McEntagart ME, Uhrig S, et al. Alterations in the ankyrin domain of TRPV4 cause congenital distal SMA, scapuloperoneal SMA and HMSN2C. Nat Genet 2010; 42:160-4. https://doi.org/10.1038/ ng. 508 .

93. Deng HX, Klein CJ, Yan J, Shi Y, Wu Y, Fecto F, et al. Scapuloperoneal spinal muscular atrophy and CMT2C are allelic disorders caused by alterations in TRPV4. Nat Genet 2010; 42:165-9. https://doi.org/10.1038/ng.509.

94. Landouré G, Zdebik AA, Martinez TL, Burnett BG, Stanescu HC, Inada $\mathrm{H}$, et al. Mutations in TRPV4 cause Charcot-MarieTooth disease type 2C. Nat Genet 2010; 42:170-4. https://doi. org/10.1038/ng.512.

95. Sulk M, Seeliger S, Aubert J, Schwab VD, Cevikbas F, Rivier M, et al. Distribution and expression of non-neuronal transient receptor potential (TRPV) ion channels in rosacea. J Invest Dermatol 2012; 132:1253-62. https://doi.org/10.1038/jid.2011.424.

96. Fusi C, Materazzi S, Minocci D, Maio V, Oranges T, Massi D, et al. Transient receptor potential vanilloid 4 (TRPV4) is downregulated in keratinocytes in human non-melanoma skin cancer. J Invest Dermatol 2014; 134:2408-17. https://doi.org/10.1038/ jid.2014.145.

97. Olivan-Viguera A, Garcia-Otin AL, Lozano-Gerona J, Abarca-Lachen E, Garcia-Malinis AJ, Hamilton KL, et al. Pharmacological activation of TRPV4 produces immediate cell damage and induction of apoptosis in human melanoma cells and HaCaT keratinocytes. PLoS One 2018; 13:e0190307. https://doi.org/10.1371/journal.pone.0190307.

98. Zheng J, Liu F, Du S, Li M, Wu T, Tan X, et al. Mechanism for regulation of melanoma cell death via activation of thermo-TRPV4 and TRPV2. J Oncol 2019; 2019:7362875. https://doi.org/10.11 $55 / 2019 / 7362875$.

99. Kida N, Sokabe T, Kashio M, Haruna K, Mizuno Y, Suga Y, et al. Importance of transient receptor potential vanilloid 4 (TRPV4) in epidermal barrier function in human skin keratinocytes. Pflugers Arch 2012; 463:715-25. https://doi.org/10.1007/s0042 4-012-1081-3.

100. Sokabe T, Tominaga M. The TRPV4 cation channel: A molecule linking skin temperature and barrier function. Commun Integr Biol 2010; 3:619-21. https://doi.org/10.4161/cib.3.6.13461.

101. Oláh A, Bíró T. Targeting cutaneous cannabinoid signaling in inflammation - A "high" -way to heal? EBioMedicine 2017; 16:3-5. https://doi.org/10.1016/j.ebiom.2017.01.003.

102. Di_Nardo A, Mascarenhas N, Wang Z. TRPV4 is a key driver for mast cell activation in LL37mediated skin inflammation. J Dermatol Sci 2017; 86:e69. https://doi.org/10.1016/j.jderm sci.2017.02.201. 